\title{
NONSPECIFIC IMMUNE RESPONSE AND RESISTANCE OF Litopenaeus vannamei FED WITH NUCLEOTIDE, $\beta$-GLUCAN, AND PROTAGEN DIETS
}

\author{
Henky Manoppo"\#, Sukenda ${ }^{* * *}$, D. Djokosetiyanto"), M. Fatuchri" ${ }^{* * *)}$, and Enang Harris ${ }^{* * *}$ \\ *) Department of Aquaculture, Faculty of Fisheries and Marine Science, Sam Ratulangi University, Manado \\ ${ }^{* *)}$ Postgraduate School of Aquaculture Department, Bogor Agricultural University, Bogor \\ ${ }^{* * *}$ Research Institute for Freshwater Aquaculture. Jl. Sempur No. 1, Bogor, West Java
}

(Received 9 February 2010; Accepted 22 April 2010)

\begin{abstract}
The objective of this research was to evaluate the nonspecific immune response and resistance of Litopenaeus vannamei fed with nucleotide, $\beta$-glucan, and protagen diets. Shrimp juveniles with an average weight of $5.39 \pm 0.56 \mathrm{~g}$ were reared in glass aquaria at a density of 15 shrimps/aquarium. Shrimps were fed three times a day for four weeks at a feeding rate of $3 \% / \mathrm{bw} /$ day. Treatment diets consisted of A: basal diet (without immunostimulant), B: $\beta$-glucan, C: protagen, and D: nucleotide, each with three replicates. At the end of feeding period, the shrimps were intramuscularly injected with Vibrio harveyi $0.1 \times 10^{6} \mathrm{cfu}_{\text {. shrimp }}{ }^{-1}$. Total haemocyte count (THC) of shrimp fed with nucleotide-diet was significantly different compared to that of control shrimp $(p=0.01)$, but not different compared to shrimp fed with protagen-diet. PO activity also increased significantly in shrimp fed with nucleotide-diet $(p=0.02)$. $\beta$-glucan diet could also increase THC and PO activity, but compared to the control, the increase was not significantly different. Overall, PO activity of shrimp fed with nucleotide, $\beta$-glucan, and protagen diets was high $(>0.35)$. Oral administration of nucleotide, $\beta$-glucan, and protagen for four consecutive weeks significantly increased resistance of shrimp to disease $(<0.01)$ where the highest resistance rate was observed on shrimp fed with nucleotide-diet. Growth of shrimp fed with nucleotide-diet was significantly different compared to that of control shrimp $(p<0.01)$, as well as to $\beta$ glucan, and protagen-treated shrimp. As a conclusion, supplementation of nucleotide into shrimp pellet enhanced nonspecific immune response and growth performance better than $\beta$-glucan, and protagen.
\end{abstract}

KEYWORDS: Litopenaeus vannamei, nucleotide, total haemocyte count, PO activity, resistance, growth

\section{INTRODUCTION}

Developing shrimp culture, especially species of Litopenaeus vannamei and Penaeus monodon, has been the main program of the Indonesian government. However, since the last two decades, many farmers and industries had suffered significant economic losses due to viral disease. WSSV destroyed the industry since 1992/1993, and starting 2006, new disease namely infectious myonecrosis virus (IMNV) has been found to infect many shrimp aquaculture in Indonesia. These two viral diseases are still unsolved.

A number of strategies that had been applied in diseases control included the use of probiotic bacteria, SPR or SPF shrimp, and

\# Corresponding author: Department of Aquaculture, Faculty of Fisheries and Marine Science, Sam Ratulangi University, Bahu Manado 95115, North Sulawesi, Indonesia. Tel.: + 62431863886

E-mail address: hmanoppo@yahoo.com 
biosecurity system. Many reports had shown that even though these methods can significantly increase production but disease still continues to occur because the susceptibility of shrimp to pathogen may differ according to life stages and the present of genetic mutation of pathogen in the environment. The use of immunostimulant is an alternative approach for disease control in shrimp aquaculture.

Immunostimulant is a substance that induces nonspecific immune response against infection of various pathogens simultaneously. This substance can be used as prophylactic treatment for unexpected disease or as suppressive treatment for latent and sub lethal pathogen (Nikl et al., 1993). Unlike vaccine, immunostimulant increases resistance of cultured shrimp against infectious pathogen simultaneously through stimulating the nonspecific immune response (Gannam \& Schrok, 2001).

Immunostimulant can be grouped into bacteria and bacterial product, yeast, carbohydrate complex, nutrition factor, animal and plant extracts, and synthetic drugs (Sakai, 1999; Sealey \& Gatlin III, 2001; Cook et al., 2003). Researches in fish and crustacean mostly used $\beta$-glucan because it occurs naturally, and no residue in fish and environment. The most common use of glucan products is Saccaharomyces cerevisiae (baker's yeast) and preparation of fungi Schizophyllum commune and Selerotium glucanicum (Sakai, 1999). Lopez et al. (2003) reported that administration of $2 \mathrm{~g}$ of $\beta$-glucan per $\mathrm{kg}$ diet could induce immune response of L. vannamei. Chang et al. (2003a) recommended the use of $2 \mathrm{~g} \beta$-glucan per $\mathrm{kg}$ diet for 24 days for shrimp $P$. monodon, while Itami et al. (1998) recommended $2 \mathrm{~g} \beta$-glucan per $\mathrm{kg}$ diet for $P$. japonicus.

This research used nucleotide as an immunostimulant. Nucleotides are semi-essential nutrient that have essential physiological and biochemical functions including encoding and deciphering genetic information, mediating energy metabolism and cell signaling as well as serving as components of coenzymes, allosteric effectors and cellular agonist (Li \& Galtin III, 2006). Application of nucleotide for disease control in aquaculture has obtained more attention since 2001. Publications concerning the application of nucleotide in fish showed that nucleotide could enhance immune response and resistance of fish against various pathogens simultaneously, increase growth and tolerance to stress. On the other hand, report on the use of nucleotide in shrimp was still unavailable or very limited. In our previous research, it was found that oral administration of nucleotide at a level of $400 \mathrm{mg}^{. \mathrm{kg}^{-1}}$ pellet significantly enhanced nonspecific immune response, resistance and growth of Litopenaeus vannamei (Manoppo et al., 2009). A comparative study with other immunostimulants is necessary to be conducted before this finding is applied in shrimp aquaculture. The objective of this research was to evaluate the nonspecific immune response, resistance and growth performance of $L$. vannamei fed with nucleotide $\beta$-glucan, and protagen diets.

\section{MATERIALS AND METHOD}

\section{Shrimp}

Shrimp juvenile (Litopenaeus vannamei) was collected from cultivation area in Bakauheni, South Lampung. Shrimps were placed into styrofoam boxes equipped with aerator and then transported to Fish Health Laboratory at the Bogor Institute of Agriculture, Bogor.

\section{Immunostimulant}

Immunostimulants used in this research consisted of pure nucleotide (Sigma-Aldrich), $\beta$-glucan, and Protagen (Diasham Resource PTE, Singapore). Nucleotide consisted of uridine5'-monophosphate disodium salt, cytidine-5'monophosphate disodium salt, guanosine-5'monophosphate disodium salt, adenosine-5'monophosphate sodium salt, and inosine-5'monophosphate disodium salt.

\section{Diet Preparation}

Nucleotide, $\beta$-Glucan, and protagen were first diluted in small amount of distilled water, mixed thoroughly into basal diet, and dried at room temperature. The mixture was then coated with albumin (egg white), and dried at room temperature. Pellet was then put into plastic bags and stored in refrigerator until used.

\section{Experimental Design}

The research was carried out using Randomized Complete Design with four treatments, each with three replicates. The treatments included: 
A. Basal diet (without immunostimulant)

B. $\beta$-glucan $2 \mathrm{~g} \mathrm{~kg}^{-1}$ pellet

C. Protagen $2 \mathrm{~g} \mathrm{~kg}^{-1}$ pellet

D. Nucleotide $0.4 \mathrm{~g} \cdot \mathrm{kg}^{-1}$ pellet

\section{Research Procedure and Data Collection}

Shrimp juveniles were reared for two weeks in 2 of 1,000 L circular fiberglass tank for adaptation process. During acclimatization, the shrimps were fed with basal diet three times a day at $09.00,13.00$, and 17.00 , with feeding rate of $3 \% / \mathrm{bw} /$ day. Juveniles were then distributed into 12 glass aquaria $(60 \mathrm{~cm} x$ $30 \mathrm{~cm} \times 30 \mathrm{~cm}$ ) each equipped with aerator and water recirculation. Each aquarium contained $50 \mathrm{~L}$ of water with 15 juveniles. Juveniles were fed with treatment diets for four weeks at a feeding rate of $3 \% / \mathrm{bw} / \mathrm{d}$ and applied three times a day at 09.00, 13.00, and 17.00 .

Sample of haemolymph for measuring immune parameters was gathered at the end of the feeding period. Haemolymph was collected according to procedure suggested by Liu \& Chen (2004). Shortly after that, about $1 \mathrm{~mL}$ of haemolymph was withdrawn from ventral sinus at the base of first abdomen using $1 \mathrm{~mL}$ syringe previously inserted with $0.1 \mathrm{~mL}$ anticoagulant. $0.8 \mathrm{~mL}$ of anticoagulant was then added to the mixture to make the ratio between haemolymph and anticoagulant 1:9.

\section{Immune Parameter}

Immune parameters measured included total haemocyte count (THC) and phenoloxidase (PO) activity. THC was counted using light microscope at 40x magnification. PO activity was measured based on dopachrome formation produced by L-DOPA. The measurement was done according to the procedure of Liu $\&$ Chen (2004). First, $1 \mathrm{~mL}$ of haemolymph-anticoagulant mixture was centrifuged at $700 \mathrm{~g}$ for 20 minutes at $4^{\circ} \mathrm{C}$. Supernatant was then removed and pellet was suspended into cacodylatecitrate buffer ( $0.01 \mathrm{M}$ sodium cacodylate, 0.45 $\mathrm{M}$ sodium chloride, $0.10 \mathrm{M}$ trisodium citrate, $\mathrm{pH} 7$ ) and centrifuged again. Pellet was suspended into $200 \mu \mathrm{L}$ cacodylate buffer $(0.01 \mathrm{M}$ sodium cacodylate, $0.45 \mathrm{M}$ sodium chloride, $0.01 \mathrm{M}$ calcium chloride, $0.26 \mathrm{M}$ magnesium chloride, $\mathrm{pH}$ 7).

Aliquot of $100 \mu \mathrm{L}$ was incubated with $50 \mu \mathrm{L}$ trypsin ( $1 \mathrm{mg} \cdot \mathrm{mL}^{-1}$ cacodylate buffer) as acti- vator for 10 minutes at $25^{\circ} \mathrm{C}-26^{\circ} \mathrm{C}$. Then, $50 \mu \mathrm{L}$ L-DOPA ( $3 \mathrm{mg} \cdot \mathrm{mL}^{-1}$ cacodylate buffer) was added, after 5 minutes, added $800 \mu \mathrm{L}$ cacodylate buffer. Optical density (OD) $490 \mathrm{~nm}$ was measured using Spectrophotometer.

\section{Resistance}

Four weeks after the feeding, the shrimps were injected intramuscularly with $0.1 \mathrm{~mL}$ of Vibrio harveyi $1 \times 10^{6} \mathrm{cfu} \cdot \mathrm{mL}^{-1}$ at the dorsal of third abdomen. During the challenge test, the shrimps were fed with basal diet three times a day at $3 \% / \mathrm{bw} / \mathrm{d}$. Mortality was observed every day for 14 days. Disease resistance was determined based on survival rate of shrimp after challenge test.

$$
\mathrm{SR}(\%)=\frac{\mathrm{Nt}}{\mathrm{No}} \times 100 \%
$$

where:

$\mathrm{SR}=$ Survival rate

$\mathrm{Nt}=$ Number of live shrimp at time $t$

No $=$ Number of live shrimp at the beginning of experiment

\section{Growth rate}

Weight gain of shrimp was measured every 2 weeks namely at day $14^{\text {th }}$ and $28^{\text {th }}$. Weight gain was calculated based on the formula of:

$$
\mathrm{G}=\mathrm{Wt}-\mathrm{Wo}
$$

where:

$\mathrm{G}=$ Weight gain

$\mathrm{Wt}=$ Final weight of shrimp $(\mathrm{g})$

Wo $=$ Initial weight $(\mathrm{g})$

\section{Data analysis}

Data were presented as mean $\pm S d$. The effect of immunostimulants on THC, PO activity, resistance, and growth of shrimp was evaluated through analysis of variance (ANOVA). Duncan Test was conducted to evaluate if there were different effects between treatments using SPSS 17 for windows.

\section{RESULTS AND DISCUSION}

\section{Total Haemocyte Count}

Supplementation of nucleotide, $\beta$-glucan, and protagen in shrimp pellet enhanced total haemocyte count (THC) of shrimp. One way ANOVA demonstrated that THC of shrimp fed with nucleotide diet was significantly differ- 
ent from that of control shrimp $(p=0.01$, Table 1), but not different compared to shrimp fed with protagen diet. After four weeks of feeding, THC increased up to $87 \%$ higher than in control shrimp. Shrimp fed $\beta$-glucan also showed an increase in THC, but the increase was not different compared to that of control shrimp.

Similar result was observed in the previous research in which THC of shrimp fed with nucleotide-diet at $400 \mathrm{mg} \cdot \mathrm{kg}^{-1}$ pellet for four weeks increased up to $76 \%$ which was higher than the control (Manoppo et al., 2009). Nucleotide is a semi essential nutrient required for growth and cell replication (Barnes, 2006). Supplementation of nucleotide in shrimp diet may optimize proliferation of cells including immune cells (Sajeevan et al., 2006). Protagen is a protein supplement (yeast extract) for fish and shrimp feed. It is known that besides protein, yeast is rich of immunostimulatory compounds such as glucan, nucleotide, and Iipopolysaccharide, thus enhanced nonspecific immune response. $\beta$-glucan had been known to induce THC of L. vannamei (Lopez et al., 2003), M. rosenbergii (Sahoo et al., 2008). $\beta$ glucan supplemented to shrimp pellet will bind to molecule receptors present at the surface of phagocyte cells (Raa, 2000). The cells then become more active for phagocytosis of pathogen or foreign particles and at the same time, they produce signal molecule (cytokine) that stimulates the production of new haemocyte.

\section{Phenoloxidase Activity}

Oral administration of nucleotide, protagen, and $\beta$-glucan increased PO activity. Analysis of variance showed that $\mathrm{PO}$ activity of shrimp fed with nucleotide-diet for four weeks was different from that of control shrimp $(p=0.02$, Table 2). PO activity observed on protagenfed shrimp was also different compared to control.

The process of nucleotide increases $\mathrm{PO}$ activity is as still unclear, but Li \& Galtin III (2006) assumed that nucleotide added to the diet will participate in cell signaling pathway as well as be used as nutrient for biosynthetic processes. It was also observed that $\beta$-glucan increased PO activity even though the different was not significant. Several reports had shown that $\beta$-glucan could enhance PO activity of $P$. monodon (Chang et al., 2003a), L. vannamei (Lopez et al., 2003), and Macrobrachium rosenbergii (Sahoo et al., 2008). $\beta$-glucan enhanced PO activity after binding to $\beta$-glucan binding protein (Li et al.,

Table 1. THC (x $10^{7}$ cell $/ \mathrm{mL}$ ) of $L$. vannamei fed nucleotide, $\beta$-glucan, and protagen diets for four weeks

\begin{tabular}{lc}
\hline \multicolumn{1}{c}{ Treatment s } & THC \\
\hline Basal diet & $1.119 \pm 0.270^{\mathrm{a}}$ \\
$\beta$-glucan & $1.422 \pm 0.175^{\mathrm{ab}}$ \\
Protagen & $1.955 \pm 0.289^{\mathrm{bc}}$ \\
Nucleotide & $2.090 \pm 0.438^{\mathrm{c}}$ \\
\hline
\end{tabular}

Mean value with different superscripts was significantly different $(p=0.01)$

Table 2. PO activity of L. vannamei fed nucleotide, $\beta$-glucan, and protagen diets for four weeks

\begin{tabular}{ll}
\hline \multicolumn{1}{c}{ Treatments } & PO activity \\
\hline Basal diet & $0.304 \pm 0.028^{\mathrm{a}}$ \\
B-glucan & $0.376 \pm 0.052^{\mathrm{ab}}$ \\
Protagen & $0.579 \pm 0.149^{\mathrm{bc}}$ \\
Nucleotide & $0.633 \pm 0.163^{\mathrm{c}}$ \\
\hline
\end{tabular}

Mean value with different superscripts was significantly different $(p=0.02)$ 
2008; Vargas-Albores \& Yepiz-Plascencia, 2000). Once it binds, inactive proenzyme PO (proPO) is activated to be PO enzyme necessary for melanization. Furthermore, Lopez et al. (2003) reported that $\beta$-glucan added to the diet will induce cell activating factors in haemocyte, thus increase PO activity and phagocytosis. In normal condition, shrimp having high THC (Table 1) displayed high PO activity too because haemocyte functions in producing and releasing proPO into haemolymph (Vargas-Albores \& YepizPlascencia, 2000). Overall, PO activity induced by nucleotide, protagen, and $\beta$-glucan was high (>0.35) (Gullian et al., 2004).

\section{Resistance}

Disease resistance was determined based on survival rate of shrimp after challenged with
Vibrio harheyi $1 \times 10^{6} \mathrm{cfu}_{\text {. shrimp }}^{-1}$ (Figure 1). Mortality occurred one day after challenge, and continued until 4 day-post challenge. Afterward, no mortality was observed in all treatments.

Application of immunostimulant nucleotide, protagen, and $\beta$-glucan positively affected the resistance of shrimp to pathogens. One way Anova showed that 28 days post-challenge, resistance of shrimp fed with these three immunostimulants was significantly different from that of control shrimp ( $p=0.003)$. Nucleotide-treated shrimp had the highest resistance rate followed by $\beta$-glucan and then protagen (Table 3).

There was no report concerning the effect of nucleotide supplementation on shrimp resistance to disease. In fish, Li et al. (2004)

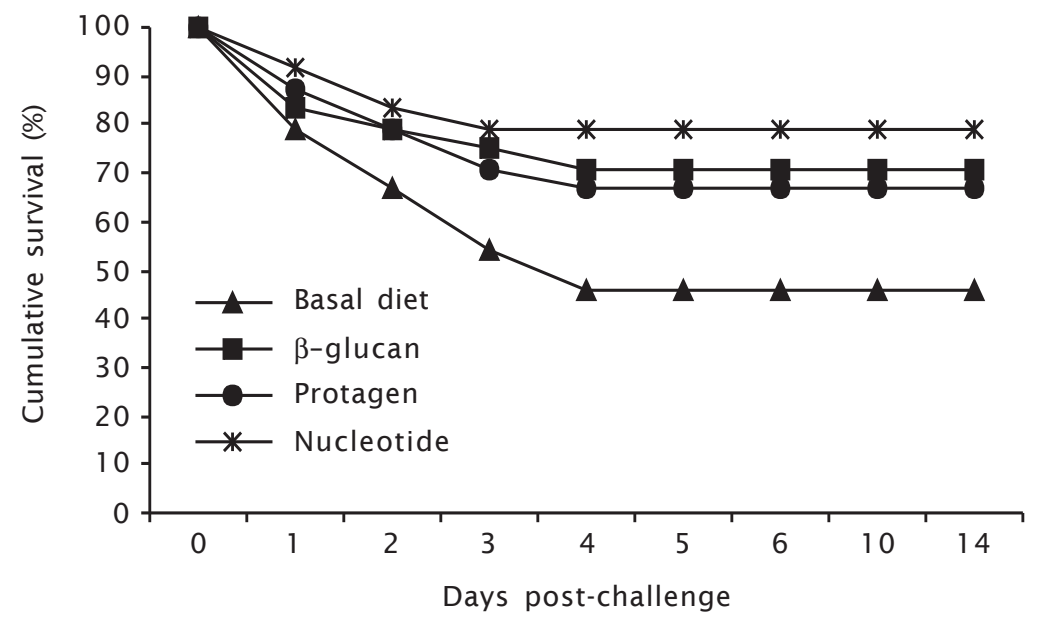

Figure 1. Cumulative survival of $L$. vannamei fed nucleotide, $\beta$-glucan, and protagen diets and challenged with Vibrio harveyi $1 \times 10^{6}$ cfu.shrimp ${ }^{-1}$

Table 3. Resistance of $L$. vannamei fed nucleotide, $\beta$-glucan, and protagen diets for four weeks and challenged with Vibrio harveyi 1 × $10^{6} \mathrm{cfu}_{\text {. shrimp }}^{-1}$

\begin{tabular}{lc}
\hline \multicolumn{1}{c}{ Treatments } & Resistance (\%) \\
\hline Basal diet & $45.83 \pm 7.22^{\mathrm{a}}$ \\
B-glucan & $70.83 \pm 7.22^{\mathrm{b}}$ \\
Protagen & $66.67 \pm 7.22^{\mathrm{b}}$ \\
Nucleotide & $79.17 \pm 7.22^{\mathrm{b}}$ \\
\hline
\end{tabular}

Mean value with different superscripts was significantly different $(p=0.03)$ 
reported that oxidative radical production of blood neutrophyl of hybrid striped bass increased after fed with nucleotide-diet for 6-7 weeks and infected with Streptococcus iniae, and survival of fish (80\%) was higher than that of fish fed free nucleotide-diet (60\%). Burrels et al. (2001) also reported that mortality of rainbow trout fed with nucleotide-diet (optimum) for 2 weeks and challenged with ISAV (infectious salmon anaemia virus) was $35.7 \%$ while mortality of fish fed basal diet was $48 \%$.

$\beta$-glucan had been proved to increase resistance of shrimps including Penaeus monodon (Chang et al., 2003a; 2003b; Song et al., 2003; Sung et al., 2001), Metapenaeus japonicus (Itami et al., 1998), and L. vannamei (Burgents et al., 2004). $\beta$-glucan induced response immune by increasing phagocytosis activity of phagocyte cells (Yin et al., 2006).

\section{Growth}

Oral administration of nucleotide, protagen, and $\beta$-glucan for 2 weeks did not induce growth of shrimp. But after feeding for 4 consecutive weeks, growth rate of shrimp fed with nucleotide-died was significantly higher than control ( $p<0.01$, Table 4 ) as well as higher than protagen and $\beta$-glucan.

Weight gain of shrimp fed with nucleotidediet was $4,73 \mathrm{~g}$ or $65,38 \%$ higher than that of shrimp fed with basal diet (Figure 2). Similar result was observed in the previous research where weight gain of shrimp fed with nucleotide-diet at $400 \mathrm{mg} \cdot \mathrm{kg}^{-1}$ pellet for 4 weeks achieved $50.74 \%$ higher than control shrimp (Manoppo et al., 2009).

Nucleotide might enhance growth through increasing feed efficiency and food intake.

Table 4. Growth performance of L. vannamei fed nucleotide, $\beta$-glucan, and protagen diets for four weeks

\begin{tabular}{lcccccc}
\hline \multirow{2}{*}{ Treat ment s } & \multirow{2}{*}{$\begin{array}{c}\text { Initial weight } \\
(\mathbf{g})\end{array}$} & \multicolumn{2}{c}{ Final weight $\mathbf{( g )}$} & & \multicolumn{2}{c}{ Weight gain $(\mathbf{g})$} \\
\cline { 3 - 4 } & & $\mathbf{1 4}^{\text {th }}$ day & $\mathbf{2 8}^{\text {th }}$ day & & $\mathbf{1 4}^{\text {th }}$ day & $\mathbf{2 8}^{\text {th }}$ day \\
\hline Basal diet & $5.39 \pm 0.56$ & $7.37 \pm 0.36^{\mathrm{a}}$ & $8.25 \pm 0.71^{\mathrm{a}}$ & & $1.98 \pm 0.36^{\mathrm{a}}$ & $2.86 \pm 0.71^{\mathrm{a}}$ \\
B-glucan & $5.39 \pm 0.56$ & $7.21 \pm 0.53^{\mathrm{a}}$ & $9.13 \pm 0.45^{\mathrm{b}}$ & & $1.82 \pm 0.53^{\mathrm{a}}$ & $3.74 \pm 0.45^{\mathrm{b}}$ \\
Protagen & $5.39 \pm 0.56$ & $7.77 \pm 0.64^{\mathrm{a}}$ & $9.24 \pm \pm 0.79^{\mathrm{b}}$ & $2.38 \pm 0.64^{\mathrm{a}}$ & $3.84 \pm 0.79^{\mathrm{b}}$ \\
Nucleotide & $5.39 \pm 0.56$ & $7.71 \pm 0.81^{\mathrm{a}}$ & $10.12 \pm 0.57^{\mathrm{c}}$ & $2.32 \pm 0.81^{\mathrm{a}}$ & $4.73 \pm 0.57^{\mathrm{c}}$ \\
\hline
\end{tabular}

Mean value with different superscripts was significantly different $(p=0.00)$

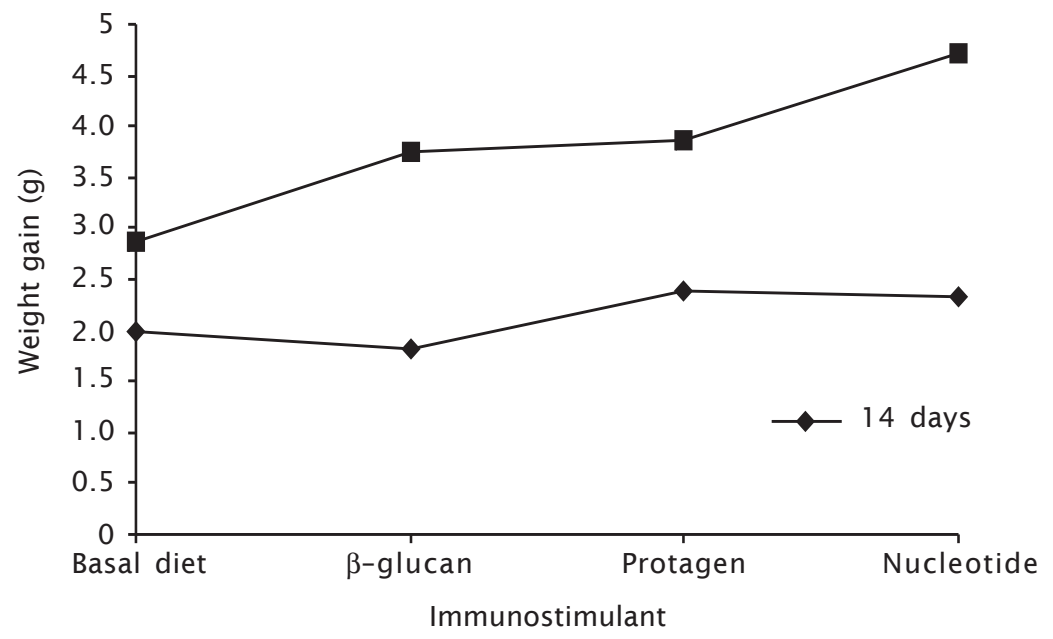

Figure 2. Weight gain of L. vannamei fed with different immunostimulans for 14 and 28 days 
Adenosine and inosine are good chemo-attractants widely used for fish and crustacean. Therefore, application of nucleotide will increase feed intake and reduce leaching of food into water (Li et al., 2007). $\beta$-Glucan added to the diet might enhance growth but how this substance works is still unclear (Lopez et al., 2003).

\section{CONCLUSION}

Application of nucleotide in shrimp culture offered more benefits than $\beta$-Glucan and protagen. Besides enhancing nonspecific immune response, it induced growth of shrimp. Further research on leaching of nucleotide into the water and its effect on shrimp need to be conducted.

\section{REFERENCES}

Barnes, A. 2006. Dietary nucleotides: Essential nutrients for shrimp growth and immunity? Centre for Marine Studies, University of Queensland, p. 1-18.

Burgents, J.E., Burnett, K.G., \& Burnet, L.E. 2004. Disease resistance of Pacific white shrimp, Litopenaeus vannamei, following dietary administration of a yeast culture food supplement. Aquaculture, 231:1-8.

Chang, C.F., Chen, H.Y., Su, M.S., \& Liao, I.C. 2003a. Immunomodulation by dietary $\beta-1,3-$ glucan in the brooders of the black tiger shrimp Penaeus monodon. Fish and shellfish Immunology, 10: 505-514.

Chang, C.F., Su, M.S., Chen, H.Y., \& Liao, I.C. 2003b. Dietary $\beta$-1,3-glucan effectively improve immunity and survival of Penaeus monodon challenged with white spot syndrome virus. Fish and Shellfish Immunology, 15: 297-310.

Cook, M.T., Hayball, P.J., Hutchinson, W., Nowak, B.F., \& Hayball, J.D. 2003. Administration of a commercial immunostimulan preparation, EcoActiva as a feed supplement enhances macrophage respiratory burst and the growth rate of snaper (Pagurus auratus, Sparidae (Bloch and Schneider) in winter. Fish and Shellfish Immunology, 14: 333345.

Gannam, A.L. \& Schrock, R.M. 2001. Immunostimulant in fish diet In Nutrition and Fish Health. Food Products Press, New York, p. 235-260.

Gullian, M., Thompson, F., \& Rodriguez, J. 2004. Selection of probiotic bacteria and study of their immunostimulatory effect in Penaeus vannamei. Aquaculture, 233: 1-14.

Itami, T., Asano, M., Tokushige, K., Kubono, K., Nakagawa, A., Takeno, N., Nishimura, H., Maeda, M., Kondo, M., \& Takahashi, Y. 1998. Enhancement of disease resistance of kuruma shrimp, Penaeus japonicus, after oral administration of peptidoglycan derived from Bifidobacterium thermophilum. Aquaculture, 164: 277-288.

Liu, C.H. \& Chen, J.C. 2004. Effect of ammonia on the immune response of white shrimp Litopenaeus vannamei and its susceptibility to Vibrio alginolyticus. Fish and Shellfish Immunology, 16: 321-334.

Li, P., Lewis, D.H., \& Galtin III, D.M. 2004. Dietary oligonucleotide from yeast RNA influence immune responses and resistance of hybrid striped bass (Morone chrysops $\times M$. saxatilis) to Streptococcus iniae infection. Fish and Shellfish Immunology, 16: 561569.

Li, P. \& Galtin III, D.M. 2006. Nucleotide nutrition in fish: Current knowledge and future application. Aquaculture, 251: 141-152.

Li, P., Lawrence, A.I., Castille, F.L., \& Galtin III, D.M. 2007. Preliminary evaluation of a purified nucleotide mixture as a dietary supplement for Pacific white shrimp Litopenaeus vannamei (Boone). Aquaculture Research, 38: 887-890.

Li, C.H., Yeh, S.T., \& Chen, J.C. 2008. The immune response of white shrimp Litopenaeus vannamei following Vibrio alginolyticus injection. Fish and Shellfish Immunology, 25: 853-860.

Lopez, N., Cuzon, G., Gaxiola, G., Taboada, G., Valenzuela, M., Pascual, C., Sanches, A., \& Rosas, C. 2003. Physiological, nutritional, and immnunological role of dietary $\beta$ glucan and ascorcic acid 2-monophosphate in Litopenaeus vannamei juveniles. Aquaculture, 224: 223-243.

Manoppo, H., Sukenda, Djokosetiyanto, D., Fatuchri, M., \& Harris, E. 2009. Nukleotida meningkatkan respon imun dan performa pertumbuhan udang vaname, Litopenaeus vannamei. Aquacultura Indonesiana, 10: 85-92.

Nikl, L., Evelyn, T.P.E., \& Albright, L.J. 1993. Trial with orally and immersion-administered $\beta$ Glucan as an immunoprophylactic against Aeromonas salmonocida. Disease of Aquatic Organisms, 17: 191-196. 
Raa, J. 2000. The use of immune-stimulant in fish and shellfish feeds. University of Thomse, Norway. Biotech ASA, Norway, p. 47-56.

Sahoo, P.K., Das, A., Mohanty, S., Mohanty, B.K., Pilai, B.R., \& Mohanty, J. 2008. Dietary B-1,3 glucan improve the immunity and disease resistance of freshwater prawn Macrobrachium rosenbergii challenged with Aeromonas hydrophyla. Aquaculture Research, 39: 1574-1578.

Sajeevan, T.P., Philip, R., \& Singh, I.S.B. 2006. Immunostimulatory effect of a marine yeast Candida sake S165 in Fenneropenaeus indicus. Aquaculture, 257: 150-155.

Sakai, M. 1999. Current research status of fish immunostimulants. Aquaculture, 172: 63-92.

Sealey, W.M. \& Galtin III, D.M. 2001 . Overview of nutritional strategies affecting the health of marine fish In Nutrition and Fish Health. Food Products Press, New York, 103-112.
Song, Y.L., Yu, C.I., Lien, T.W., Huang, C.C., \& Lin, M.N. 2003. Haemolymph parameters of Pacific white shrimp (Litopenaeus vannamei) infected with Taura Syndrome Virus. Fish and Shellfish Immunology, 14: 317-331.

Sung, H.H., Hsu, S.F., Chen, C.H., Ting, Y.Y., \& Chao, W.L. 2001. Relationships between disease outbreak in cultured tiger shrimp (Penaeus monodon) and the composition on Vibrio communities in pond water and shrimp hepatopancreas during cultivation. Aquaculture, 192: 101-110.

Vargas-Albores, F. \& Yepiz-Plascencia, G. 2000. Beta glucan binding protein and its role in shrimp immune response. Aquaculture, 191: 13-21.

Yin, G., Jeney, G., Racs, T., Xu, P., Jun, X., \& Jeney, Z. 2006. Effect of two Chinese herbs (Astragalus radix and Scutellaria radix) on nonspesific immune system of tilapia, Oreochromis niloticus. Aquaculture, 253: 39-47. 